\title{
Changes in ovine cervical mucus in response to oestrogen treatment
}

\author{
N. R. Adams and B. Y. Tang \\ Division of Animal Health, CSIRO, Institute of Agriculture, University of Western Australia, \\ Nedlands, Western Australia 6009
}

\begin{abstract}
Summary. After 10 days pretreatment with $10 \mathrm{mg}$ progesterone daily, ovariectomized ewes were injected i.m. with $12 \cdot 5,25,50$ or $100 \mu \mathrm{g}$ oestradiol benzoate (OB) and cervical mucus was collected 16, 24, 32, 40 and $48 \mathrm{~h}$ later (Exp. 1), or were injected with $12 \cdot 5,40$ or $100 \mu \mathrm{g}$ OB daily, and the mucus examined, for 9 days (Exp. 2). The Spinnbarkeit was affected by the dose of OB over 9 days, but at all doses it increased over the first 3 days of treatment (Exp. 2). The wet weight of the mucus, the amount and proportion of water, and therefore the degree of arborization, increased with the dose of OB but decreased after 3 days in Exp. 2. The amount of dry matter, protein or carbohydrate did not have any clear relationship to dose or duration of $O B$ treatment.
\end{abstract}

\section{Introduction}

The cervix acts as a reservoir and a regulator of sperm flow through the reproductive tract of many mammals, including ewes (Mattner, 1963) and women (Settlage, Motoshima \& Tredway, 1973). The physical nature of the cervical mucus varies greatly throughout the oestrous or menstrual cycle and plays a vital role in these functions (Mattner, 1969; Davajan, Nakamura \& Kharma, 1970). An alteration of the physical properties of mucus by concurrent progestagen treatment of women (Elstein et al., 1976) or after prolonged exposure of ewes to oestrogenic pasture (Adams, 1976) leads to interference with sperm transport and reduces the likelihood of fertilization. The physical properties of mucus are also believed to be responsible for its ability to maintain the viability of spermatozoa in vitro (Mattner, 1969).

Despite the importance of the physical properties of cervical mucus, the manner in which these properties respond to hormonal treatment has not been systematically studied. The following experiments were designed to study some of the effects of various doses of and durations of treatment with oestrogen on the cervical secretion of mucus by ovariectomized ewes.

\section{Materials and Methods}

Eighty-one (81) mature Merino ewes were obtained from areas free of oestrogenic subterranean clover and ovariectomized 8 months before the studies. Each treatment group contained 10 ewes which were treated intramuscularly (i.m.) with $10 \mathrm{mg}$ progesterone (Aldrich Chemical Co., Milwaukee) in oil, daily for 10 days. After $48 \mathrm{~h}$ the ewes were treated i.m. with oestradiol benzoate (Intervet [Aust.], Sydney) in oil as indicated in the 'Results'.

Samples of mucus were collected by aspirating all available mucus from around the cervical os into a $1 \mathrm{ml}$ pipette, which was then sealed and kept at $4^{\circ} \mathrm{C}$ until the mucus was examined. The mucus was blown onto a preweighed glass slide to determine the Spinnbarkeit and the wet weight as described previously (Adams, 1976). In Exp. 1 and the preliminary study in Exp. 2, dry weight 
of the mucus was determined after drying at $60^{\circ} \mathrm{C}$ for $48 \mathrm{~h}$. The degree of arborization of the mucus was scored from 1 to 10 , depending on the proportion of the secretion covered by crystals. This scoring system gave similar results to that used previously to study arborization in cervical mucus from ewes with clover infertility (Adams, 1976) but was easier to apply.

In Exp. 2, after the determination of Spinnbarkeit, the mucus was rinsed into a tube with 5 volumes of $0.15 \mathrm{M}$-sodium thiocyanate in $0.9 \%(\mathrm{w} / \mathrm{v}) \mathrm{NaCl}$ solution (Wolf, Sokoloski, Khan \& Litt, 1977). The mixture was left in ice for $1 \mathrm{~h}$, followed by centrifugation at $700 \mathrm{~g}$ and $4{ }^{\circ} \mathrm{C}$ for $15 \mathrm{~min}$. The supernatant was used for the determination of protein by the method of Lowry, Rosebrough, Farr \& Randall (1951) and carbohydrate by that of Hewitt (1937). The pellet was retained for estimation of DNA by the fluorometric method of Setaro \& Morley (1976).

Data were analysed by split-plot analysis of variance. Because of the great variability, the data on total weight and weight of protein in Exp. 2 were transformed to $\log _{10}$ values for analysis, and values for arborization score were subjected to arc-sine transformation.

\section{Results}

\section{Experiment 1: effects of single doses of oestradiol benzoate}

As shown in Table 1, increasing doses of oestradiol increased the total wet weight of mucus collected and the arborization score but decreased the proportion of dry weight in the mucus. There was no significant effect of oestrogen dose or sampling time on the dry weight of mucus collected. There was no overall effect of oestradiol dose on Spinnbarkeit, but there was a significant interaction for Spinnbarkeit between dose and time of sampling. Spinnbarkeit

Table 1. Effect of dose (D) of oestradiol benzoate and time (T) of sampling on characteristics of cervical mucus, after a single injection

\begin{tabular}{|c|c|c|c|c|c|c|c|}
\hline \multirow[b]{2}{*}{ Characteristic } & \multirow[b]{2}{*}{ Dose $(\mu \mathrm{g})$} & \multicolumn{5}{|c|}{ Time (h) } & \multirow[b]{2}{*}{ Variance ratio } \\
\hline & & 16 & 24 & 32 & 40 & 48 & \\
\hline Wet wt (mg) & $\begin{array}{l}12 \cdot 5 \\
25 \\
50 \\
100\end{array}$ & $\begin{array}{r}64 \\
199 \\
189 \\
306\end{array}$ & $\begin{array}{r}82 \\
333 \\
418 \\
531\end{array}$ & $\begin{array}{l}150 \\
165 \\
348 \\
404\end{array}$ & $\begin{array}{l}162 \\
235 \\
525 \\
609\end{array}$ & $\begin{array}{l}111 \\
224 \\
427 \\
466\end{array}$ & $\begin{array}{l}D: F_{3,36}=9 \cdot 57^{* *} \\
T: F_{4,144}=4 \cdot 31^{*} \\
T \times D: F_{12,144}=<1\end{array}$ \\
\hline Dry wt (mg) & $\begin{array}{l}12 \cdot 5 \\
25 \\
50 \\
100\end{array}$ & $\begin{array}{r}4 \cdot 6 \\
9 \cdot 2 \\
10 \cdot 7 \\
9 \cdot 0\end{array}$ & $\begin{array}{r}4 \cdot 5 \\
7 \cdot 4 \\
10 \cdot 7 \\
9 \cdot 0\end{array}$ & $\begin{array}{l}5 \cdot 3 \\
4 \cdot 4 \\
6 \cdot 0 \\
6 \cdot 2\end{array}$ & $\begin{array}{l}5 \cdot 5 \\
5 \cdot 3 \\
8 \cdot 0 \\
8 \cdot 7\end{array}$ & $\begin{array}{l}5 \cdot 5 \\
4 \cdot 8 \\
7 \cdot 8 \\
9 \cdot 2\end{array}$ & $\begin{array}{l}D: F_{3,36}=2 \cdot 64 \\
T: F_{4,144}=1.95 \\
T \times D: F_{12,144}=<1\end{array}$ \\
\hline$\%$ dry matter & $\begin{array}{l}12 \cdot 5 \\
25 \\
50 \\
100\end{array}$ & $\begin{array}{l}6 \cdot 35 \\
6 \cdot 04 \\
5.62 \\
3.28\end{array}$ & $\begin{array}{l}5 \cdot 60 \\
3.43 \\
3.30 \\
1.84\end{array}$ & $\begin{array}{l}5 \cdot 23 \\
3 \cdot 11 \\
1 \cdot 74 \\
1 \cdot 69\end{array}$ & $\begin{array}{l}4 \cdot 59 \\
3 \cdot 64 \\
1 \cdot 63 \\
1 \cdot 29\end{array}$ & $\begin{array}{l}7 \cdot 05 \\
3 \cdot 38 \\
2 \cdot 03 \\
2 \cdot 43\end{array}$ & $\begin{array}{l}D: F_{3,36}=13 \cdot 22^{* * *} \\
T: F_{4,144}=13 \cdot 53^{* * *} \\
T \times D: F_{12,144}=1 \cdot 92^{*}\end{array}$ \\
\hline $\begin{array}{l}\text { Spinnbarkeit } \\
(\mathrm{cm})\end{array}$ & $\begin{array}{l}12 \cdot 5 \\
25 \\
50 \\
100\end{array}$ & $\begin{array}{l}3 \cdot 9 \\
4 \cdot 2 \\
9 \cdot 0 \\
4 \cdot 4\end{array}$ & $\begin{array}{l}5 \cdot 0 \\
3 \cdot 9 \\
5 \cdot 7 \\
4 \cdot 6\end{array}$ & $\begin{array}{l}4 \cdot 9 \\
5 \cdot 7 \\
5 \cdot 7 \\
4 \cdot 9\end{array}$ & $\begin{array}{l}4 \cdot 1 \\
5 \cdot 7 \\
8 \cdot 3 \\
9 \cdot 0\end{array}$ & $\begin{array}{r}4 \cdot 4 \\
6 \cdot 5 \\
12 \cdot 5 \\
10 \cdot 2\end{array}$ & $\begin{array}{l}D: F_{3,36}=2 \cdot 45 \\
T: F_{4,144}=7 \cdot 40^{* * *} \\
T \times D: F_{12,144}=2 \cdot 26^{*}\end{array}$ \\
\hline $\begin{array}{l}\text { Arborization } \\
\text { score }\end{array}$ & $\begin{array}{l}12 \cdot 5 \\
25 \\
50 \\
100\end{array}$ & $\begin{array}{l}1 \cdot 1 \\
2 \cdot 1 \\
1 \cdot 1 \\
4 \cdot 9\end{array}$ & $\begin{array}{l}2 \cdot 1 \\
4 \cdot 9 \\
6 \cdot 7 \\
7 \cdot 9\end{array}$ & $\begin{array}{l}1 \cdot 7 \\
3 \cdot 6 \\
5 \cdot 5 \\
6 \cdot 2\end{array}$ & $\begin{array}{l}2 \cdot 2 \\
2 \cdot 7 \\
7 \cdot 6 \\
7 \cdot 1\end{array}$ & $\begin{array}{l}1 \cdot 2 \\
4 \cdot 1 \\
6 \cdot 6 \\
5 \cdot 1\end{array}$ & $\begin{array}{l}D: F_{3,36}=10 \cdot 68^{* * *} \\
T: F_{4,144}=7 \cdot 02^{* * *} \\
T \times D: F_{12,144}=2 \cdot 04^{*}\end{array}$ \\
\hline
\end{tabular}

${ }^{*} P<0.5 ;^{* *} P<0.01 ;^{* * *} P<0.001$. 
increased in ewes on the higher doses after $32 \mathrm{~h}$. An interaction between dose and time of sampling was also observed for arborization score and the proportion of dry weight in mucus.

Material was recovered from less than half the ewes when sampled before treatment with oestradiol, so that valid comparison with pretreatment values could not be made.

\section{Experiment 2: effects of continued treatment with oestradiol benzoate}

In a preliminary experiment in 11 ewes injected i.m. with $25 \mu \mathrm{g}$ oestradiol benzoate daily for 9 days, the Spinnbarkeit, the total weight of mucus, the proportion of water and the arborization score declined sharply after 3 days treatment, but the total amount of dry matter recovered remained relatively constant. In the main experiment, the amounts of carbohydrate, protein and DNA (to indicate the amount of sloughed cells) were estimated to determine whether the different components of the dry matter varied during the experimental period.

Table 2. The effect of the dose of oestradiol benzoate on mean daily values for characteristics of cervical mucus during daily stimulation and collection over 9 days

\begin{tabular}{|c|c|c|c|c|}
\hline \multirow[b]{2}{*}{ Characteristic } & \multicolumn{3}{|c|}{ Oestradiol dose $(\mu \mathrm{g})$} & \multirow{2}{*}{$\begin{array}{l}\text { Variance ratio } \\
\left(\mathbf{F}_{2,27}\right)\end{array}$} \\
\hline & 12 & 40 & 100 & \\
\hline Spinnbarkeit (mm) & 107 & 128 & 80 & $3 \cdot 88^{*}$ \\
\hline Wet wt (mg) & 136 & 148 & 173 & $1 \cdot 13$ \\
\hline Protein $(\mu \mathrm{g})$ & 448 & 356 & 485 & 0.25 \\
\hline Carbohydrate $(\mu \mathrm{g})$ & 92 & 77 & 76 & 0.19 \\
\hline DNA $(\mu \mathrm{g})$ & 465 & 457 & 427 & 0.13 \\
\hline Conc. of protein $(\mu \mathrm{g} / 0.02 \mathrm{ml})$ & 105 & 79 & 93 & 0.79 \\
\hline Conc. of carbohydrate $(\mu \mathrm{g} / 0.02 \mathrm{ml})$ & 18 & 16 & 13 & $4 \cdot 15^{*}$ \\
\hline
\end{tabular}

$* P<0.05$.

Significant $(P<0.001)$ variation over time was noted in the Spinnbarkeit, the total amount of mucus, the concentrations of protein and carbohydrate, the amounts of DNA and carbohydrate, and also $(P<0.01)$ in the amount of protein collected (Text-fig. 1). There were no statistically significant interactions between dose and time. The Spinnbarkeit, but not the weight, increased significantly over the first 3 days. Apart from an increase on Day 3, no consistent pattern was seen in the total amount of protein or carbohydrate collected (Text-fig. 1b). The total amount of DNA varied erratically (Text-fig. 1d). The concentration of protein increased throughout the experiment, while the concentration of carbohydrate remained constant after Day 4.

The effects of different doses of oestradiol benzoate given over the 9 days are shown in Table 2. The Spinnbarkeit was greatest at a dose of $40 \mu \mathrm{g}$, and least at a dose of $100 \mu \mathrm{g}(P<0.05)$. In this experiment, the increase in amount of mucus with increasing doses was not significant. The concentration of carbohydrate was inversely proportional to the dose $(P<0.05)$, but a similar trend for the concentration of protein was significant only on Day 1 (concentrations after doses of $12.5,40$ or $100 \mu \mathrm{g}$ oestradiol being 72,32 and $12 \mu \mathrm{g} / 100 \mu \mathrm{l}: \mathrm{F}_{2 \cdot 27}=6 \cdot 74, P<0.01$ ). There was no effect of dose on the total amount of protein, carbohydrate or DNA. Analysis of the results for the first 3 days only did not change any of these conclusions.

\section{Discussion}

This study showed that the amount and the nature of cervical mucus depended on the dose of oestradiol benzoate, and the length of time over which it is administered. This dual dependency 
(6n) u!

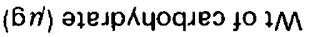

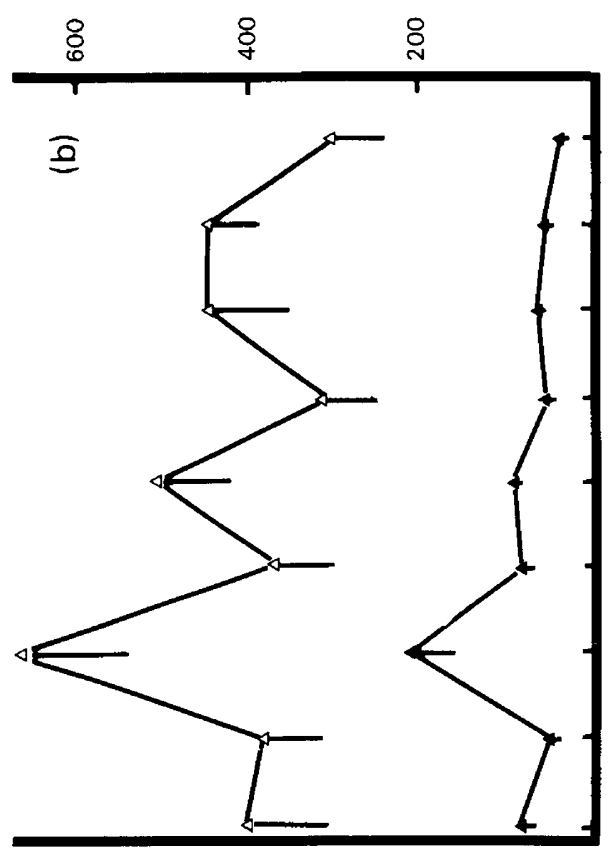

$\left(6 n^{\prime}\right) \forall N O$ to IM

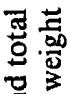

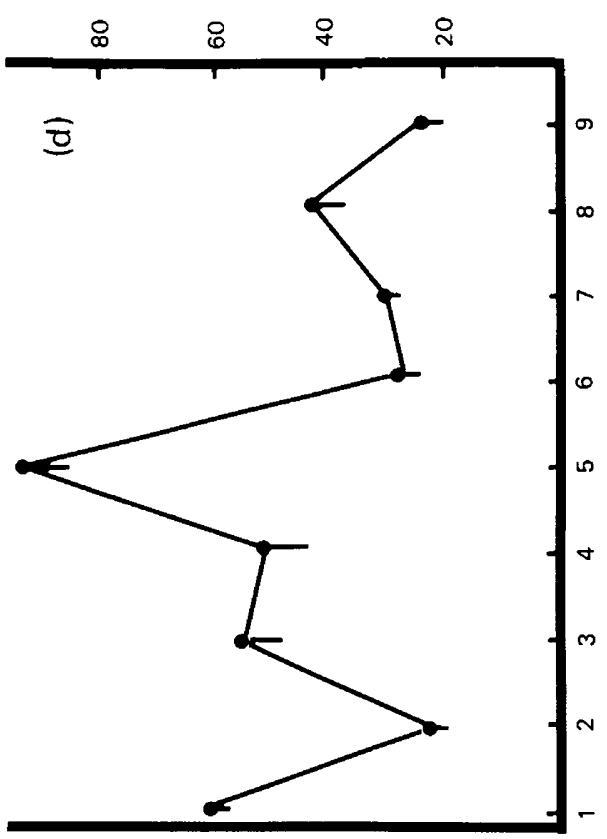

를

Q

莺官

苋

放㐘

홍

范

䆑急

므

눈

긍

壱

唹宁

충.

今

$\vec{\circ}$

营

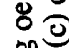

(uv) y! aysequu!ds

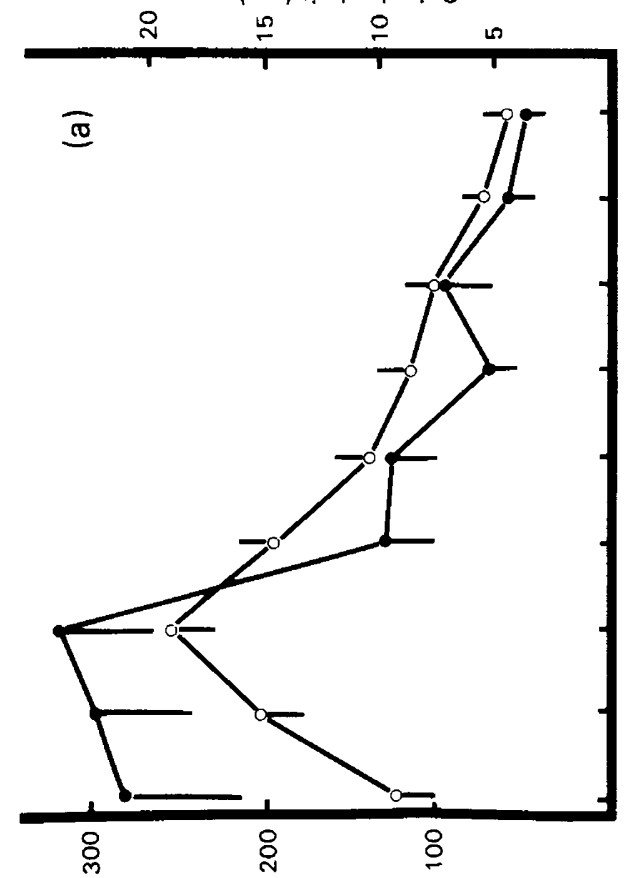

(6U) IM 1 E)०

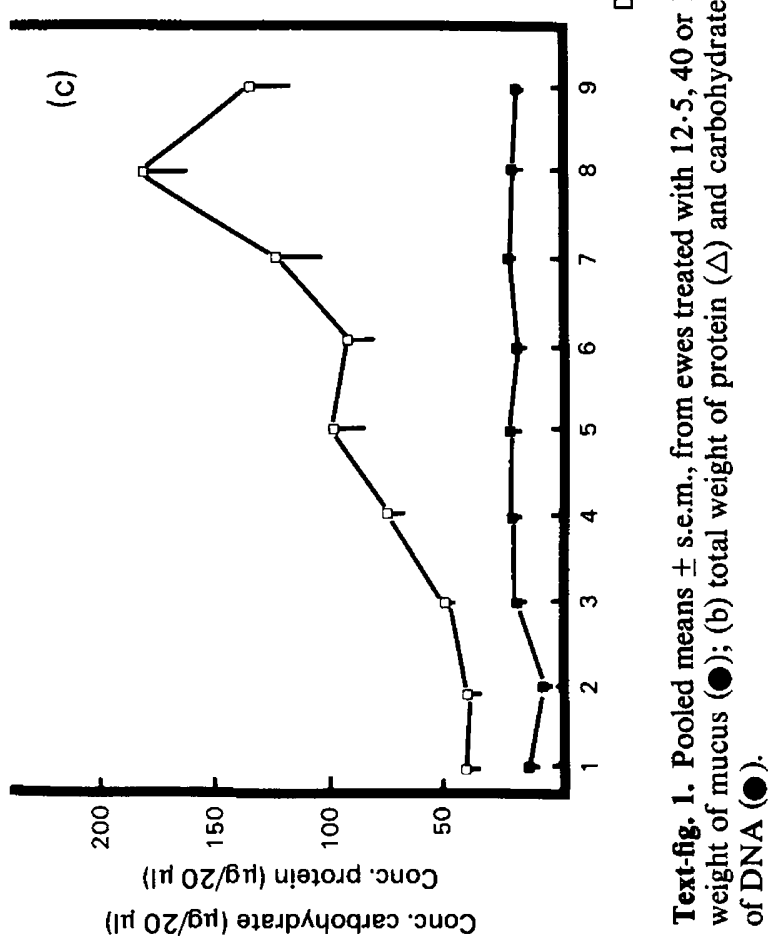


was particularly clear for Spinnbarkeit in Exp. 2, but was also apparent in Exp. 1. Large doses of oestradiol benzoate lead to more prolonged plasma levels of oestrogen (e.g. Yuthasastrakosol, Howland, Simaraks \& Palmer, 1974), and it is suggested that, in Exp. 1, the doses of 50 and $100 \mu \mathrm{g}$ oestradiol acted for long enough to allow some oestrogenic 'priming' of the Spinnbarkeit response.

The increase in Spinnbarkeit over the first 3 days in Exp. 2 could not be readily related to changes in the total amount of mucus, in the proportion of water in the mucus, or to the amounts or relative proportions of carbohydrate or protein in the mucus. It must therefore have been due to qualitative changes within the protein or carbohydrate components of the mucus, even though Gibbons (1969) has pointed out that such changes are not very great. The biochemical basis for the lower Spinnbarkeit in ewes treated with $100 \mu \mathrm{g}$ oestradiol is not obvious but may be analogous to the poor Spinnbarkeit seen in cervical mucus from "hyperoestrogenic" women (Odeblad, 1969) and in ewes after prolonged grazing on oestrogenic pasture (Adams, 1976).

The dose and the duration of oestradiol treatment influenced the total amount of mucus collected. The findings in Exp. 1 for the dose relationship confirm those reported previously (Lindsay \& Francis, 1968). This relationship did not achieve statistical significance in Exp. 2, possibly because of the less frequent sampling and the great variability in sample size. The effect of the duration of exposure to oestradiol was clearly seen in the decline in the amount of mucus collected after Day 3 in Exp. 2.

In contrast, neither the dose nor the duration of oestradiol treatment affected the amount of dry matter in the mucus, or any of its components. Thus, although oestradiol affects the type of mucoprotein secreted (as argued above) it has no effect on the amount of mucoprotein. Smith (1971), who used the less sensitive cotton swab technique, was also unable to relate dose to the amount of dry matter secreted. Oestrogen must therefore control both the amount of mucus and the proportion of water in the mucus simply by controlling the amount of water secreted by the cervix. The influence of the dose of oestradiol on the proportion of water in the mucus was seen in both the present experiments and the arborization score followed this proportion, as shown previously by Zondek \& Rozin (1954). The proportion of water in mucus is important because it determines the penetrability of the mucus for spermatozoa (MacDonald \& Lumley, 1970). The Spinnbarkeit of mucus, unrelated to the changes in the water content, reflects its ability to guide sperm migration (Adams, 1975). While the proportion of water in the mucus depended largely on the dose of oestradiol, the increase in Spinnbarkeit depended mainly on the time for which the ewe had been exposed. The production of mucus optimal for sperm transport must therefore depend upon both the degree and the duration of oestrogenic stimulation.

The assistance of M. R. Sanders is gratefully acknowledged.

\section{References}

Adams, N.R. (1975) Relationship between cervical mucus spinbarkheit and the direction of sperm migration in ewes with clover disease. $J$. Reprod. Fert. 43, 391-392.

Adams, N.R. (1976) Cervical mucus changes in infertile ewes previously exposed to oestrogenic subterranean clover. Res. vet. Sci. 21, 59-63.

Davajan, V., Nakamura, R.M. \& Kharma, K. (1970) Spermatozoan transport in cervical mucus. Obstetl. Gynec. Surv. 25, 1-43.

Elstein, M., Morris, S.E., Groom, G.V., Jenner, D.A., Scarisbrick, J.J. \& Cameron, E.H.D. (1976) Studies on low-dose oral contraceptives: cervical mucus and plasma hormone changes in relation to circulating Dnorgestrol and $17 \alpha$-ethynyl estradiol concentrations. Fert. Steril. 27, 892-899.
Gibbons, R.A. (1969) The composition of mucus with special reference to its rheological properties. In Protides of the Biological Fluids, Proceedings of the 16th Colloquium, pp. 299-305. Ed. H. Peeters. Pergamon Press, Oxford.

Hewitt, L.F. (1937) Separation of serum albumin into two fractions. II. Observations on the nature of the glycoprotein fraction. Biochem. J. 31, 360-366.

Lindsay, D.R. \& Francis, C.M. (1968) Cervical mucus measurement in ovariectomized ewes as a bioassay of synthetic and phytooestrogens. Aust. J. agric. Res. 19, 1069-1076.

Lowry, O.H., Rosebrough, N.J., Farr, A.L. \& Randall, R.J. (1951) Protein measurement with the Folin phenol reagent. J. biol. Chem. 193, 265-275. 
MacDonald, R.R. \& Lumley, I.B. (1970) Sperm penetration of cervical mucus. The role of saline. $\mathrm{Am}$. J. Obstet. Gynec. 107, 846-851.

Mattner, P.E. (1963) Spermatozoa in the genital tract of the ewe. II. Distribution after coitus. Aust. J. biol. Sci. 16, 688-694.

Mattner, P.E. (1969) The survival of spermatozoa in bovine cervical mucus and mucus fractions. $J$. Reprod. Fert. 20, 193-199.

Odeblad, E. (1969) Types of human cervical secretion. Acta Eur. Fertil. 1, 99-116.

Setaro, F. \& Morley, C.G.D. (1976) A modified fluorometric method for the determination of microgram quantities of DNA from cell or tissue cultures. Analyt. Biochem. 71, 313-317.

Settlage, D.S.F., Motoshima, M. \& Tredway, D.R. (1973) Sperm transport from the external cervical os to the Fallopian tubes in women: a time and quantitation study. Fert. Steril. 24, 655-661.
Smith, J.F. (1971) Studies on ovine infertility in agricultural regions of Western Australia: cervical mucus production by fertile and infertile ewes. Aust. J. agric. Res. 22, 513-519.

Wolf, D.P., Sokoloski, J., Khan, M.A. \& Litt, M. (1977) Human cervical mucus. III. Isolation and characterization of rheologically active mucin. Fert. Steril. 28, 53-58.

Yuthasastrakosol, P., Howland, B.E., Simaraks, S. \& Palmer, W.M. (1974) Estrogen-induced LH release in progesterone-treated ovariectomized ewes. Can. J. Anim. Sci. 54, 565-572.

Zondek, B. \& Rozin, S. (1954) Cervical mucus arborization: its use in the determination of corpus luteum function. Obstet. Gynec. 3, 463-470.

Received 12 October 1978 